\title{
Threats to the Critically Endangered endemic Bermudian skink Eumeces longirostris
}

\author{
John Davenport, Jeremy Hills, Anne Glasspool and Jack Ward
}

\begin{abstract}
The Bermudian rock lizard or skink Eumeces longirostris is categorized as Critically Endangered on the 2000 IUCN Red List. Skinks are vulnerable to habitat loss, introduction of non-native species and mortality caused by discarded bottles and cans that act as selfbaiting traps. This study describes the population characteristics of the Bermudian skink on two islands of the Bermudian archipelago: Nonsuch and Southampton islands. Nonsuch Island is a nature reserve but has populations of introduced lizards of the genus Anolis, lizard-eating birds and (a new finding) the cane toad Bufo marinus. Southampton Island is relatively isolated and has no introduced species. The skink population on Nonsuch Island was not investigated in detail, but appears to be small, localized to human habitation (where cover and food scraps are available) and dom-
\end{abstract}

inated by large, old (some possibly $>27$ years) animals that exhibit high mutilation rates. Breeding occurs, but survival to adulthood appears poor. All of neighbouring Southampton Island was intensively trapped, with traps placed at the intersections of a $10-\mathrm{m}$ grid. The population was estimated by mark-recapture trials to be $c .400$ adults and juveniles; hatchlings are insectivorous and not susceptible to trapping. The population on Southampton Island is currently the largest known on Bermuda and appears to be viable; sustained isolation from predators and people is essential to its maintenance.

Keywords Bermuda, Critically Endangered lizards, Eumeces longirostris, skinks.

\section{Introduction}

The Bermudian rock lizard or skink Eumeces longirostris is the only endemic terrestrial vertebrate on the isolated archipelago of Bermuda. It is a relatively primitive 'relict' species of the widespread genus Eumeces (Taylor, 1936), identifiable on Bermuda from Pleistocene deposits (Wingate, 1965), but probably resident for hundreds of thousands of years. The closest relative appears to be E. fasciatus of south-eastern USA (Heilprin, 1889).

The Bermudian skink is poorly known, except in those features amenable to direct observation. Notes on reproduction were made from five skinks kept in captivity at Bermuda Aquarium, Museum and Zoo since 1984. Three hatchlings were 'discovered' in the terrarium in August 1984, seven skinks hatched in JulyAugust 1985, and in July 1986 a nest of five eggs was discovered under a rock and shortly thereafter a hatchling was seen (Barnes \& Eddy, 1987). R. Marirea

J. Davenport (Corresponding author) University Marine Biological Station, Millport, Isle of Cumbrae, UK; Present address: Department of Zoology and Animal Ecology. University College Cork, Lee Maltings, Prospect Row, Cork, Ireland. E-mail: jdavenport@zoology.ucc.ie

J. Hills University Marine Biological Station, Millport, Isle of Cumbrae, UK

A. Glasspool and J. Ward Bermuda Aquarium, Natural History Museum and Zoo, PO Box FL 145, Flatts, FL BX, Bermuda

Revised manuscript accepted for publication 3 July 2001 (pers. comm.) has a photograph of a dissected skink with six eggs. Taken together these observations suggest that breeding takes place each year in the summer and that clutch size is $5-6$. However, there is no indication of whether females lay clutches every year, or more than once in a season.

The species' lifespan is essentially unknown, although some skink species are known to survive in captivity for many years - an experimental colony $(n \approx 100)$ of similarly sized desert skinks Chalcides ocellatus from Egypt showed no adult mortality during a 12-year period (J. Davenport, pers. obs.). H. Griffith, D.B. Wingate \& D.L. Robinson (unpublished data) used toeclipping in studies on Nonsuch Island (Fig. 1) during the 1960s, but abandoned these in 1970. Several large lizards collected in the present study were missing toes, suggesting that individuals may live more than 27 years. It is not known when Bermudian skinks become sexually mature or what their growth rates are. Another captive colony is to be established by the Bermuda Aquarium, Museum of Natural History and Zoo, and if successful, some of these basic questions may be answered.

Colouration of Bermudian skinks changes markedly during development. Recently hatched skinks ('hatchlings') have sky blue tails and striped bronze, cream and chocolate bodies. Juvenile and subadult animals progressively lose first the blue coloration of the dorsal tail 


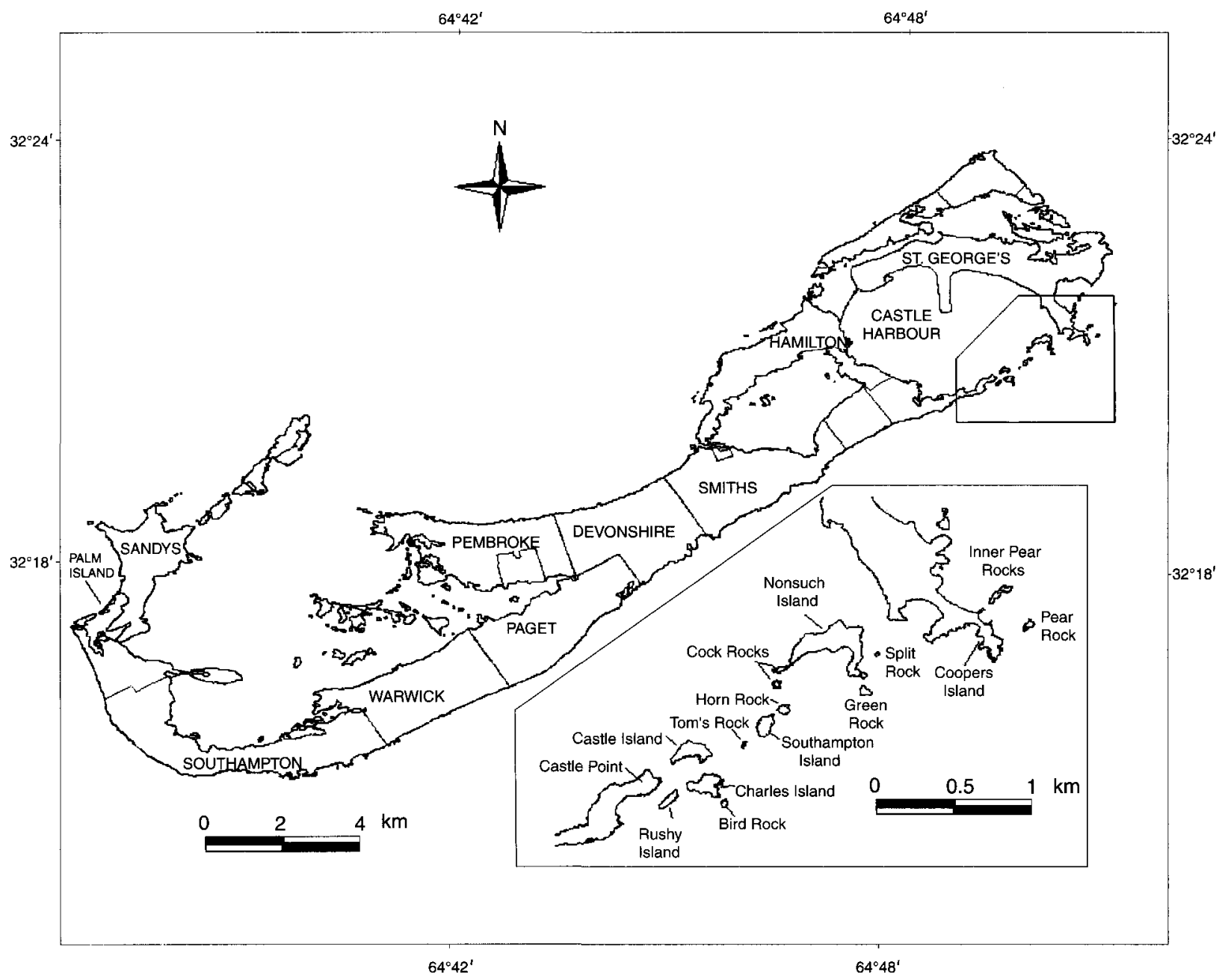

Fig. 1 Bermuda, with parishes, showing locations of islands mentioned in the text.

surface, then the bronze dorsal colour and stripes, and acquire an orange chin and cheeks. Apparently fully adult animals have dark upper surfaces (marbled tan or blue or black), a blue belly and an orange chin and cheeks. We emphasize that 'hatchling', 'juvenile', 'subadult' and 'adult' are imprecise terms; the duration of each stage is unknown, and it is unclear whether 'adults' are the only sexually mature stages.

The Bermudian skink is believed to be strictly insectivorous as a hatchling, but juveniles, subadults and adults also take substantial quantities of carrion, especially that associated with sea bird nests (in particular the cahow Pterodroma cahow and the white-tailed tropic bird or longtail Phaethon lepturus). Carrion taken includes broken eggs, dead chicks, and regurgitated fish and squid (Wingate, 1965; Garber, 1988; D.B. Wingate, pers. comm.).

The Bermudian skink is listed as Critically Endangered on the 2000 IUCN Red List (Conyers, 1996; HiltonTaylor, 2000), based on criteria B1 +2 bcde, i.e. extent of occurrence $<100 \mathrm{sq} \mathrm{km}$ or area of occupancy $<10 \mathrm{sq} \mathrm{km}$ (B), severely fragmented (1), and with continued decline (2), in area of occupancy (b), in area, extent and/or quality of habitat (c), in number of locations or subpopulations (d), and in number of mature individuals (e). However, there is no specific legislative protection for the skink, although island beaches are equipped with litter bins, notices explain the risks posed by discarded drink containers, and poster campaigns raise awareness in schools. The Bermuda Biodiversity Strategy and Action Plan is being prepared and coordinated by the Bermuda Zoological Society, supported through the UK Darwin Initiative.

Once common throughout Bermuda (Wingate, 1965), skink populations have declined throughout the archipelago, although Wingate thought the species more common inland than generally recognized (disputed by Garber (1988), who believed the skink to have been rare for many years). Habitat loss has undoubtedly been a factor over much of the archipelago. The native habitat 
of forests and swamps has largely been replaced by agriculture, which covers 17 per cent of the archipelago, and homes and gardens, which occupy 50 per cent of land area (Thomas \& Logan, 1992).

A study in the early 1990s by H. Griffith, D.B. Wingate \& D.L. Robinson (unpublished data) on Nonsuch Island (Fig. 1), a nature reserve (6.8 ha) with restored natural vegetation, revealed evidence of a serious population decline over a 20-year period despite habitat loss not being a contributory factor. The decline has been attributed to predation by introduced and reintroduced species (D.B. Wingate, pers. comm.). These include kiskadees (Pitangus sulphuratus, lizard-eating birds deliberately introduced in 1957 to control anoles but often observed to take skinks), night herons (Nyctanassa violacea, reintroduced to replace long-extinct native herons in 1976-78 and observed to regurgitate skink remains in pellets) and Jamaican anoles (Anolis grahami, introduced in 1905 to control scale insects on crops and seen to prey on young skinks (D.B. Wingate, unpublished data)). Other than night herons and a fossil hawk there appear to have been no native skink predators on pre-colonial Bermuda. It is worth noting that Cope (1861), writing before the introduction of any other reptiles or amphibians but after much habitat loss, described the skink as 'very common', but Verrill (1902) described its status after the introduction in 1885 of the predatory toad Bufo marinus (to control cockroaches) as 'by no means common except in particular localities'.

Before the present study it was thought that the neighbouring Castle Harbour Islands (Southampton, Castle, Charles and Inner Pear islands, Fig. 1), where introduced species are largely absent, might support the only remaining viable populations of Bermudian skinks. However, Castle and Charles islands are easily accessible, and discarded bottles and drink cans cause significant mortality by attracting and trapping lizards, which are then killed by the heat of the sun; their carcasses attract yet more skinks and a single bottle can kill a dozen animals (D.B. Wingate, pers. comm.). Although Inner Pear and Southampton islands are both inaccessible to casual boat use and thus free from such litter, the former is very small (0.2 ha). Therefore, Southampton Island (1.04 ha) is potentially the only truly safe haven for Bermudian skinks.

The present study, carried out in 1997, was triggered by the proposition that an archaeological dig be carried out at a Jacobean fort on Southampton Island. The Parks Department, Ministry of Works and Engineering, decided that permission for a dig would not be given, pending investigation of the distribution and characteristics of the skink population. Moreover, the categorization of the skink as Critically Endangered prompted the Ministry to give consideration to more extensive man- agement of the species. The report from the present study was regarded as a key first step towards design of a full management plan. Preliminary work was carried out on Nonsuch Island to determine whether the population decline there was continuing and to test survey techniques.

\section{Methods}

Nonsuch Island (Fig. 1) has extensive restored natural Bermudian vegetation, is a nature reserve, and is visited by relatively large numbers of people. Southampton Island, to the south-west (Fig. 1), is barren and waterless by comparison and, because access is difficult, visitors are few. Except in a narrow band of bare rocky coast, the island supports extensive crab grass Stenotaphrum secundatum interspersed with Spanish bayonet Yucca aloifolia, prickly pear Opuntia dilleni, seaside goldenrod Solidago sempervirens, lantana Lantana involucrata and Bermudiana Sisyrinchium bermudiana. The only shade is provided by a few scattered mixed bay grape Coccoloba uvifera and tamarisk Tamarix gallica stands. Potentially predatory bird life is largely limited to the occasional kiskadee. At the southern end of the island is Southampton Fort, built shortly after Bermuda's colonization in 1612 .

Work carried out on Nonsuch Island was preliminary, particularly in terms of trapping and bait. However, it was intended that a number of lizards should be captured, to permit some evaluation of population characteristics. Thirty-four traps (glass jars mounted close to upright position, with rocks or vegetation placed so that skinks could gain access) were deployed throughout the island and in as wide a range of habitat types as possible. Traps were baited with a mixture of dogfood and tuna fish, which was effective but difficult to clean from traps; it also attracted ants. Trapping took place between 10.00 and 16.00 on 21 July 1997. Snout to vent length (SVL) was measured to the nearest $\mathrm{mm}$ on captured skinks, colouration and any deficiencies of tail structure or limb morphology were recorded, and individuals were marked with a small dot of enamel paint so that recaptured animals would not be remeasured. As there were several people describing animals in the field, and because judgement of colour is subjective, we only described animals as adults (dark dorsum, no striping; usually $>76 \mathrm{~mm}$ SVL), subadults/juveniles (identifiable striping, often blue-tailed; usually $<78 \mathrm{~mm}$ SVL) or hatchlings (brown body, bright blue tail).

Trapping on Southampton Island was more systematic. On 25 July 1997, 73 traps were positioned on the intersections of a $10 \times 10 \mathrm{~m}$ grid, marked with short pieces of orange plastic tape attached to rocks or vegetation, over the whole of the island. Each trap was 
a plastic or glass jar at $c .45^{\circ}$, shaded by palmetto fronds. In preference to dogfood/tuna bait, traps were baited with a small quantity of crushed sardine in a polypropylene cup. Cod liver oil was smeared around the rim of the trap to reinforce the olfactory signal, to make the rim slippery to reduce the chance of skinks escaping, and to deter ants.

Baiting of traps started at c. 09.00 on 26 July 1997, and each trap was then inspected at hourly intervals until c. 18.00. A complete inspection of all traps took c. $30 \mathrm{~min}$, and therefore counts of trapped lizards were assigned to $09.30,10.30$ and so on up to 17.30. Trapped lizards were removed to a polythene bag within an ice-cooled box for a few minutes to reduce activity levels. Morphometry and colouration were measured or noted as described for Nonsuch specimens, and individuals were marked with a trap-specific combination of narrow stripes of enamel paint, either on the back or tail or on both back and tail.

Baiting and capture of skinks was repeated for $9 \mathrm{~h}$ from $c .09 .00$ on the following 2 days. The trap of initial capture of previously marked skinks was identified, and the right forelimb and right hindlimb were then painted with the colour code of the trap in which the skink had been recaptured, allowing the animal to be identified as a previous recapture if it was caught for a third time. All skinks captured over the 3 days were released within $0.5 \mathrm{~m}$ of the trap.

To investigate any potential effect of environmental temperature on skink capture, air temperature was recorded to $0.1{ }^{\circ} \mathrm{C}$ in the shade and in open sunlight at intervals over the three days using an electronic thermometer (KM200, Cole Palmer).

\section{Results}

Twenty-three skinks were captured on Nonsuch Island (Table 1), in only eight of the 34 traps, and 12 skinks
(52 per cent) were caught in a single trap close to the main building on the island. Although the Nonsuch survey was relatively coarse (i.e. substantial distances between traps), these data indicate localized populations and a concentration around human habitation.

In total 123 skinks were caught in 34 of the 73 traps on Southampton (Table 1, Fig. 2); 43 skinks were marked and released on day 1,69 unmarked and eight marked animals were captured during days 2 and 3 , and three animals escaped before being fully measured and marked. Few skinks were caught in the central and western regions of the island, and most captures were within $10 \mathrm{~m}$ or less of the southern fort and at the northwest of the island where there were a number of longtail nests. Of the eight recaptured skinks, four were found in the same trap that they were first captured in, and four in a neighbouring trap (i.e. $10 \mathrm{~m}$ from the original), indicating that trap spacing was near-ideal and that short-term mobility was low.

Using the Lincoln (or Petersen) index, which depends on marked skinks mixing thoroughly with unmarked animals and all animals having the same chance of being captured (Greenwood, 1996), the population size can be estimated as (no. recaptured $\times$ no. initially marked) $/$ (no. marked recaptures $)$, giving $((8+69) \times 43) / 8=414$. The population estimated at the time of each recapture (Fig. 3) fell asymptotically from 881 after the 1st recapture to 403 after the 8 th, with little change after six recaptures. Four hundred and fourteen is a minimum population estimate, because a few small areas of Southampton Island were close to cliff edges or otherwise too dangerous for trapping. In addition, the traps did not capture hatchlings, which are wholly insectivorous and appear not to be attracted by the scent of food.

Capture rate was low early in the morning, peaked at about 12.30, and fell sharply in the afternoon (Fig. 4). This pattern may be temperature-related; at 09.00-09.30

Table 1 Summary of data collected from Bermudian skinks trapped on Nonsuch and Southampton islands in July 1997.

\begin{tabular}{|c|c|c|c|c|c|c|c|c|c|c|}
\hline \multirow[b]{2}{*}{ Island } & \multirow[b]{2}{*}{$\begin{array}{l}\text { No. skinks } \\
\text { captured }\end{array}$} & \multicolumn{3}{|c|}{ Number $(\%)$ of skinks in each age class } & \multirow{2}{*}{$\begin{array}{l}\text { Percentage of } \\
\text { traps catching } \\
\text { skinks }\end{array}$} & \multirow{2}{*}{\multicolumn{2}{|c|}{$\begin{array}{l}\text { Snout vent } \\
\text { length }(\mathrm{mm})\end{array}$}} & \multirow[b]{2}{*}{$\begin{array}{l}\text { Mutilation } \\
\text { rate (\%) }\end{array}$} & \multicolumn{2}{|c|}{ Catch per unit effort as } \\
\hline & & Adult & $\begin{array}{l}\text { Subadult/ } \\
\text { juvenile }\end{array}$ & Hatchling & & & & & $\begin{array}{l}\text { Trap hours } \\
\text { per skink }\end{array}$ & $\begin{array}{l}\text { Man hours } \\
\text { per skink }\end{array}$ \\
\hline \multirow[t]{4}{*}{ Nonsuch } & $23^{\mathrm{a}}$ & $19(86)$ & $2(9)$ & $1(5)$ & 23.5 & $n$ & 22 & 55 & 8.9 & 0.92 \\
\hline & & & & & & Median & 87 & & & \\
\hline & & & & & & Mean & 83 & & & \\
\hline & & & & & & SD & 12.3 & & & \\
\hline \multirow[t]{4}{*}{ Southampton } & $123^{b}$ & $68(60.2)$ & $45(39.8)$ & $0(0)$ & 47.0 & $n$ & 107 & 21 & 14.2 & 2.60 \\
\hline & & & & & & Median & 77 & & & \\
\hline & & & & & & Mean & 75 & & & \\
\hline & & & & & & $\mathrm{SD}$ & 7.6 & & & \\
\hline
\end{tabular}

${ }^{a}$ Twenty-two fully measured.

'Three animals escaped before being fully marked and measured, 107 animals were measured. 


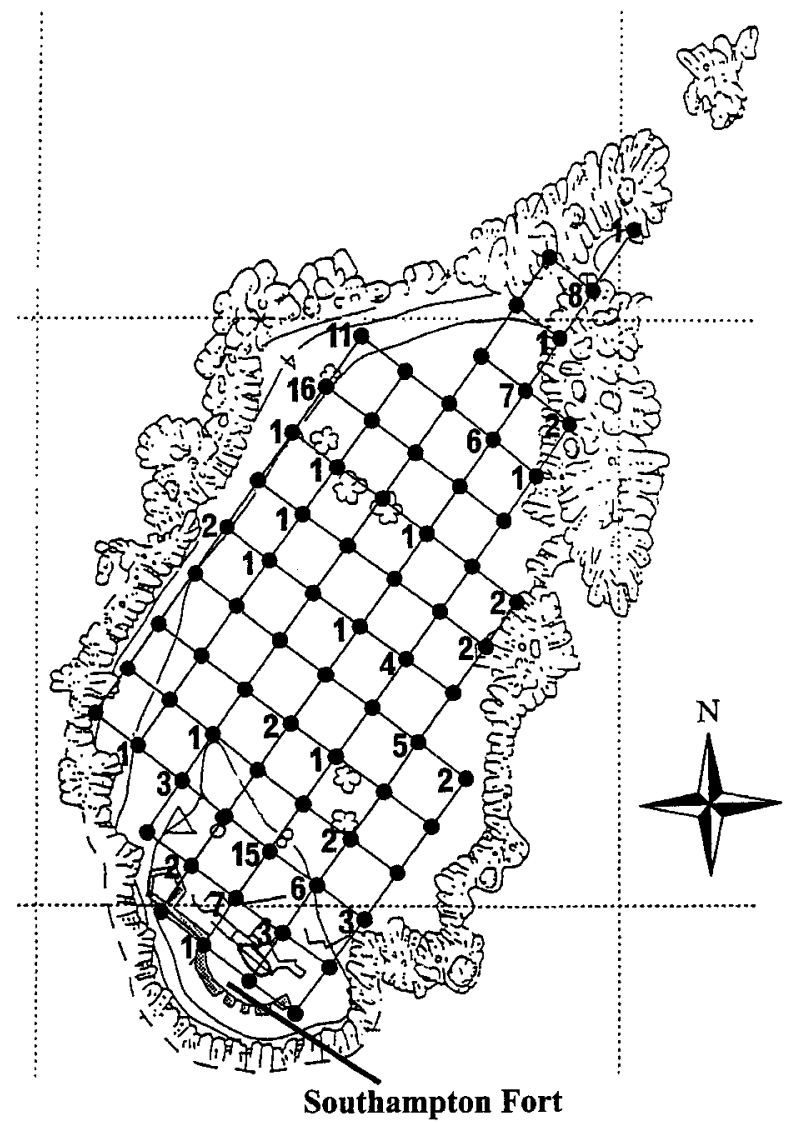

Fig. 2 Southampton Island, showing spatial distribution of captured skinks. Numerals refer to the number of animals caught in particular traps. Note that the grid indicated by filled circles (the trap locations) is composed of $10 \mathrm{~m}$ squares. The dotted lines indicate $100 \mathrm{~m}$ distances in $\mathrm{N}-\mathrm{S}$ and $\mathrm{E}-\mathrm{W}$ directions.

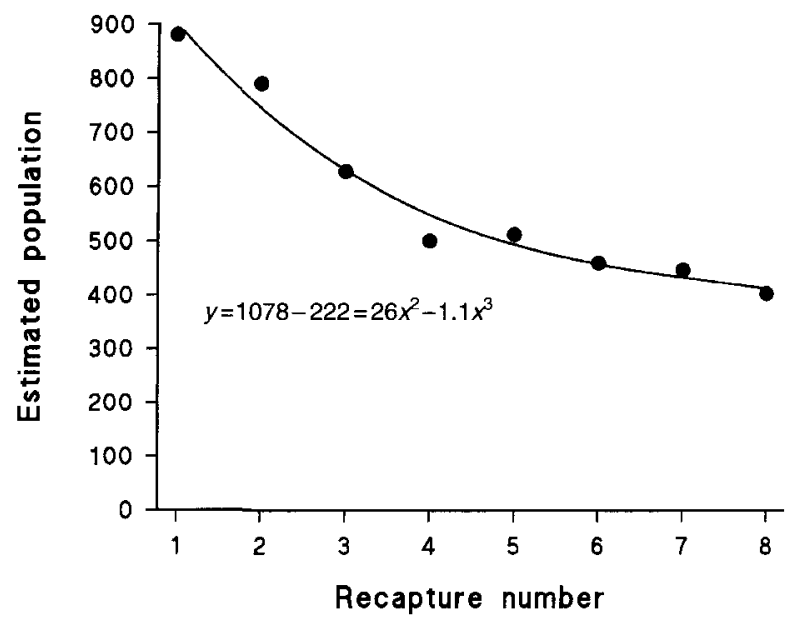

Fig. 3 Relationship between estimated Southampton Island skink population size (calculated using the Lincoln Index; solid circles) and the number of marked skinks that had been recaptured at the time of the estimate.

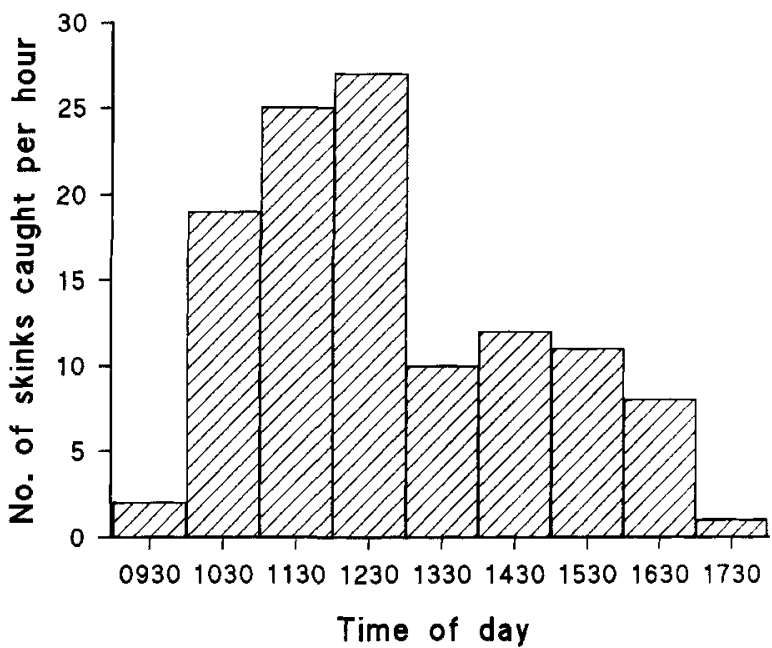

Fig. 4 Relationship between skink capture rate on Southampton Island and time of day (summed for 3 days).

shade temperatures were around $31-32{ }^{\circ} \mathrm{C}$; by about 11.30 they had risen to $35^{\circ} \mathrm{C}$, and by 13.30 to about $38^{\circ} \mathrm{C}$, at which time the temperature in the sun was $45-47^{\circ} \mathrm{C}$, a lethal temperature for lizards, if sustained.

The catch per unit effort, expressed as trap hours or number of man-hours per skink captured, was greater on Nonsuch than on Southampton Island, although this does not take account of the effort involved in gridding Southampton Island, or in setting out unbaited traps before the Southampton mark-recapture exercise, nor does it include travelling or preparation time for either island.

The median SVL of skinks on Nonsuch was $87 \mathrm{~mm}$ (Table 1, Fig. 5). With the exception of a single hatchling

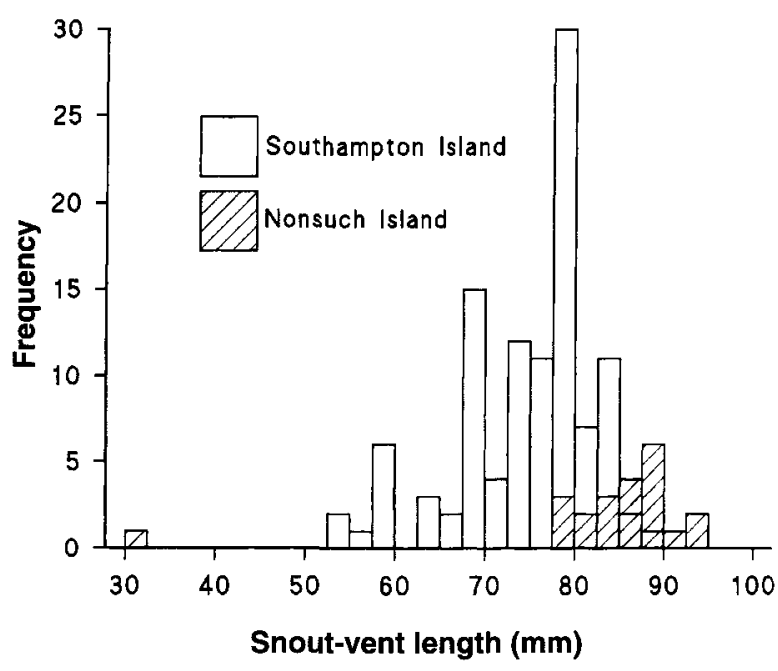

Fig. 5 Size distribution of snout-vent length (SVL, in mm) in skinks from Nonsuch and Southampton islands. 
(SVL $32 \mathrm{~mm}$ ), no animals were smaller than SVL $78 \mathrm{~mm}$, and SVL was not normally distributed (AndersonDarling test (Shin, 1996): $n=22, \mathrm{~A}^{2}=3.024, P<0.001$ ). On Southampton SVL was also not normally distributed (Anderson-Darling: $n=107, \mathrm{~A}^{2}=2.330, P<0.001$ ) and the median was $77 \mathrm{~mm}$. Nonsuch animals were significantly larger than those of Southampton (median test: $x^{2}=14.56, \mathrm{df}=1, P<0.001$ ), although this must be interpreted cautiously because the Southampton sample was reflective of the whole island whereas that of Nonsuch was not.

Signs of mutilation (damaged tails and/or digit loss of varying degrees) were significantly higher on Nonsuch than on Southampton Island (Table $1 ; \chi^{2}$ test $=10.86$, $P<0.01)$. Two factors could be responsible for the difference: the larger, and presumably older, animals on Nonsuch may have accumulated more mutilations simply because of their longer life, or they may have included individuals that had their toes clipped in the 1960s (H. Griffith, D.B. Wingate \& D.L. Robinson, unpublished data).

A markedly higher proportion of subadult/juvenile skinks were trapped on Southampton than on Nonsuch Island (Table 1), and although no hatchlings were trapped on Southampton Island, several were seen. One hatchling ( $32 \mathrm{~mm}$ SVL) was captured on Nonsuch Island and other hatchlings-of-year were seen, as was mating behaviour between adults. A single specimen of B. marinus was captured in a Nonsuch skink trap.

\section{Discussion}

Southampton Island appears to have a viable skink population of around 400 individuals, with a full range of size classes. Roughly 40 per cent of animals were juveniles or subadults, similar to the situation in other viable island skink populations (e.g. Hikida, 1981). Assuming that 60 per cent of the population was fully adult and reproductively competent, there would have been 240 breeding adults in the July 1997 population, and because most vertebrates have a $1: 1$ sex ratio, 120 of these would have been adult females. Assuming annual breeding, five eggs per clutch (Barnes \& Eddy, 1987; R. Marirea, pers. comm.) and 100 per cent egg survival to hatching, the colony should produce c. 600 hatchlings per annum. This is a reasonable estimate because 100 per cent egg survival is unlikely, but it is probable that some 'subadult' animals are capable of breeding. In 1970 the Nonsuch population exhibited characteristics similar to the present Southampton population (H. Griffith, D.B. Wingate \& D.L. Robinson, unpublished data), but with the proviso that the data are based on a small sample, the Nonsuch Island population of skinks now appears to be in serious decline. Most of the trapped animals were large adults and there were no middle-sized animals, despite the presence of recent hatchlings and observations of mating. Although H. Griffith, D.B. Wingate and D.L. Robinson (unpublished data) found a marked decline in subadult numbers between 1971 and 1991, they were still catching animals in the size range $60-75 \mathrm{~mm}$ in 1991. These size classes were totally absent in our study, albeit limited. Our new record of introduced cane toads (present on the mainland of Bermuda since 1885) is an additional predatory threat on Nonsuch Island. There is also anecdotal evidence from the Bermudian mainland that the Bermudian skink may consume toadlets and be poisoned by bufotoxin (D.B. Wingate, unpublished data).

Skinks were not evenly distributed around Southampton Island; they were concentrated on the landward side of the fort, and near the north-west shoreline close to longtail nests. Longtail nests are known to be a source of carrion eaten by skinks (D.B. Wingate, pers. comm.). Skinks were commonly trapped near bay grape, but were found in most types of vegetation, and often on bare rock. The range of the Bermudian skink, at least over short periods, is small (c. $10 \mathrm{~m}$ in diameter; Wingate, 1998; J. Conyers, pers. comm.; this study). An archaeological dig in and around the fort upon Southampton Island would therefore create great disturbance to concentrations of skinks, and would also risk introduction of predators such as rats, mice and toads.

We presented catch per unit effort data to help the design of future surveys of the Bermudian skink. Values of 8.9 trap-hours (Nonsuch) and 14.2 trap-hours (Southampton) per skink captured superficially suggest that skink densities were higher on Nonsuch. However, the Nonsuch survey was limited, few Nonsuch traps caught skinks (23.5 per cent versus 47 per cent on Southampton Island), and 52 per cent of skinks caught on Nonsuch were in a single trap, indicating a highly localized concentration of skinks.

A particular concern for skink conservation in Bermuda is the existence of multiple small populations. This may reflect separation caused by habitat loss and fragmentation, and thus carry the risks of inbreeding and genetic drift combining to reduce fitness. Alternatively, the populations may each be genetically distinct, with implications for any captive breeding programmes or management by translocation. The Bermuda chain consists of over 120 islands, many of them connected by causeways and bridges constructed over the past three centuries to form a 'mainland'. However, all of the islands are relatively close to one another and separated by shallow channels that would have been emergent during periods of low sea level as 
recently as 6000 years ago (W. Sterrer, pers. comm.). So, even before human intervention, there may have been sufficient land bridges and subsequent interisland migration, presumably by rafting or swimming, to maintain gene flow.

The median size of Nonsuch skinks was much greater than that of Southampton animals, but this was primarily because small size classes were absent on Nonsuch. However, absolute maximum size was also greater on Nonsuch ( $94 \mathrm{~mm}$ SVL) than on Southampton Island ( $90 \mathrm{~mm} \mathrm{SVL),} \mathrm{and} \mathrm{one} \mathrm{Nonsuch}$ animal showing remnants of juvenile striping was $83 \mathrm{~mm}$ long, far larger than any such animal on Southampton Island. Two explanations might be advanced; firstly that they are genetically different, and secondly that food supply, and hence growth, on Nonsuch Island is better, particularly with the availability of scraps around habitation. Data collected recently by Raine (1998) also reveals size differences amongst populations. Skinks on Inner Pear Island were small (max SVL $81 \mathrm{~mm}$ ), skinks on Charles Island (max SVL $92 \mathrm{~mm}$ ) were similar in size to those on Southampton Island, and skinks from Spittal Pond on the mainland ( $\max$ SVL $88 \mathrm{~mm}$ ) were much smaller than those in the Nonsuch population. Further morphometric analysis would seem futile because of the small sizes of the populations; similar reservations apply to any attempts to quantify differences in available food supply. A proper genetic analysis, using modern molecular techniques, is needed.

A recent study of four other Bermudian sites in 1998 has reinforced the importance of Southampton Island as a refuge for $E$. longirostris. Using similar techniques to those employed in the present study, Raine (1998) estimated the size of skink populations on Inner Pear Island (52) and Charles Island (123), plus a mainland nature reserve site at Spittal Pond (124), whereas Wingate (1998) estimated the population of Palm Island (44). Although all four of these populations showed reasonable proportions of juvenile and adult lizards, none are large enough to have confidence in their longterm future. The population on Southampton Island is currently the largest known on Bermuda and appears to be viable. It is crucial that this population be protected effectively, and sustained isolation from predators and people is essential to its maintenance. Recognizing the importance of this population the Parks Commission, which has jurisdiction over the island, resolved to disallow the proposed archaeological dig as a direct result of the present study. Ideally, landings on the island should only be by permission of the Parks Commission and efforts should be made to ensure that introduced species, particularly other lizard species and the cane toad, remain excluded.

\section{Acknowledgements}

This is contribution no. 35, Bermuda Biodiversity Project (BBP), Bermuda Aquarium, Natural History Museum and Zoo. The authors are grateful for invaluable conversations with James Conyers and David Wingate who have a wealth of knowledge about skink biology. They are also especially grateful to Julia Davenport, Bonnie Coy and Guy Miller who assisted in the field. Thanks are due to Zara Ward for computerizing handwritten records, to Joseph Furbert for producing the Bermuda map and Heather De Silva for providing land zoning data. The Parks Department, Ministry of Works and Engineering kindly provided financial support for this study.

\section{References}

Barnes, J.A. \& Eddy, F. (1987) Captive reproduction of the Bermuda rock lizard or skink (Eumeces longirostris). Animal Keeper's Forum, 14, 239-240.

Conyers, J. (1996) Bermuda skink listed as critically endangered. Critter Talk, 19, 9.

Cope, E.D. (1861) On the Reptilia of Sombrero and Bermuda. In Proceedings of the Academy of Natural Sciences, Philadelphia, USA.

Garber, S.D. (1988) Behavior and ecology of the endangered endemic Bermuda rock lizard (Eumeces longirostris). In Proceedings of the 12th International Symposium on Captive Propagation and Husbandry, pp. 67-69.

Greenwood, J.J.D. (1996) Basic techniques. In Ecological Census Techniques: A Handbook (ed. W. J. Sutherland), pp. 11-110. Cambridge University Press, Cambridge, UK.

Heilprin, A. (1889) The Bermuda Islands - A Contribution to the Physical History and Zoology of the Somers Archipelago. Heilprin, Philadelphia, USA.

Hikida, T. (1981) Demography of an island population of the lizard, Eumeces okadae, on Miyake-Jima, Izu Islands. Research in Population Biology, 32, 119-133.

Hilton-Taylor, C. (compiler) (2000) 2000 IUCN Red List of Threatened Species. IUCN, Gland, Switzerland and Cambridge, UK.

Raine, A. (1998) A Study of Morphological Differentiation, Fluctuating Asymmetry and the Threats Facing Isolated Populations of the Critically Endangered Bermuda Rock Lizard. MSc Thesis, University College London, London, UK.

Shin, K. (1996) Minitab Guide. Irwin Statistical Software Series 2nd edn. McGraw-Hill, Chicago, USA.

Taylor, E.H. (1936) A taxonomic study of the cosmopolitan scincoid genus Eumeces with an account of the distribution and relationships of its species. Kansas University Scientific Bulletin, 23, 1-643.

Thomas, M.L.H. \& Logan, A. (1992) A Guide to the Ecology of Shoreline and Shallow-water Marine Communities in Bermuda. BBSR Special Publication No. 30, 346 pp.

Verrill, A.E. (1902) The Bermuda Islands - an account of the scenery, climate, production, physiography, natural history and geology with sketches of their discovery and early 
history, and changes in the flora and fauna due to man. Transactions of the Connecticut Academy of Science, 11, 413-956. Wingate, D.B. (1965) Terrestrial herpetofauna of Bermuda. Herpetologica, 21, 202-218.

Wingate, R.S. (1998) A Comparison of Demography and Morphological Variation in Two Insular Populations of the Bermuda Rock Lizard (Eumeces longirostris). BSc Dissertation, University of Wales, Swansea, UK.

\section{Biographical sketches}

Prof. John Davenport is Head of the Department of Zoology and Animal Ecology and Director of the Environmental Research Institute at University College Cork, Ireland. He has worked extensively on marine turtles, crocodilians and lizards.

Dr Jeremy Hills works as a coastal manager at the Centre for Coastal Management at the University of Newcastle upon Tyne in the UK. He is involved in developing integrated coastal habitat conservation and management strategies.

Dr Annie Glasspool has a background in marine biology and has worked in Bermuda since 1987. She has been the Project Leader of the Bermuda Zoological Society's Bermuda Biodiversity Project since 1997.

Mr Jack Ward was employed as the Government Fisheries Biologist in Bermuda for 12 years before becoming the Curator of the aquarium and zoo at the Bermuda Aquarium, Museum and Zoo in 1992. He became Principal Curator in 1999. 